Ahmed S. Hashad, Mohamed I. Abukhashaba, Seismic evalution of cracked masonary barrage piers repaired with different methods, pp. $1406-1420$

\title{
SEISMIC EVALUTION OF CRACKED MASONRY BARRAGE PIERS REPAIRED WITH DIFFERENT METHODS
}

\author{
AHMED S. HASHAD", MOHAMED I. ABUKHASHABA
}

Construction Research Institute, Delta Barrages, Egypt

Received 28 May 2013, accepted 22 June 2013

\begin{abstract}
The most common defects observed in masonry structures are cracking due to tensile stresses. Repairing process is needed to restore the structural capacity of the distressed masonry piers. Crack repair methods used in rehabilitation of water structures that have been built using clay bricks may affect the performance of those structures during their resistance to seismic loads. This research deals with evaluating the common methods used to repair major cracks of masonry piers. The evaluation process considered the performance of the repaired piers under the influence of seismic loads. Dynamic tests using shaking table with harmonic excitation were carried out to represent the effect of seismic loads. Therefore, the current paper investigates the dynamic structural performance of cracked masonry barrage piers, which are repaired using different techniques. Three different techniques are used for the purpose of repairing the cracked piers namely; epoxy pasted-repair, stapled using reinforced bars, and tied using pre-stressed technique. Four masonry piers were built on a shaking table and they were exposed to cyclic loads with different frequencies to simulate the earthquake. It was observed that the type of repair technique used affects the load carrying capacity of the piers and leads to a redistribution of the strains and hence stresses in repaired piers. All repair techniques are found to be able to restore or enhance the dynamic structural behavior for all the repaired piers that can stand against lateral loads with efficiency more than the uncracked pier. Guidelines for the assessment of the use of epoxy, reinforced and pre-stressed repair techniques in construction and strengthening of masonry barrages were suggested. For tied technique, some cautions must be considered when applied to overcome the base shear failure.
\end{abstract}

Keywords: Masonry, Piers, Earthquake, Crack Repair, Epoxy- Pasted, and Pre-Stressed.

\section{Introduction}

Major cracks in different structures may occur due to overloading, lack/corrosion of reinforcement, seismic loading and differential settlement of supports. To restore the structural capacity of the distressed elements, repairing process is needed. In practice, for a variety of reasons, situations arise where existing masonry structures or some of their components may be found to be inadequate and in need of repair and/or retrofitting. The inadequacy may be due to mechanical damage, functional changes, overstress due to temperature changes, or harsh environmental exposure [1]. There are several methods available for repairing different structural elements reported in the literature. Different repair techniques have been successfully developed to strengthen a given structure or part of it to restore its serviceability and strength. Repair methods used to repair defects and cracks may have little effects or not commensurate with its economic cost. It is also prudent to consider durability aspect when repair or strengthening is carried out. With the advancement of new materials technology, which have superior mechanical properties and excellent resistance to electrochemical corrosion, many effective repairs and strengthening techniques have been developed. The final selection of a suitable and most effective

\footnotetext{
* Corresponding author.

E-mail address: a@earth-egypt.com
} 
Ahmed S. Hashad, Mohamed I. Abukhashaba, Seismic evalution of cracked masonary barrage piers repaired with different methods, pp. $1406-1420$

method generally depends on simplicity, speed of application, structural performance and total cost.

Carbon fiber reinforced polymer (CFRP) has a high strength to weight ratio, favorable fatigue behavior and excellent resistance to electrochemical corrosion to make it practically suited for structural application [2]. A study conducted by [3] found that the failure modes for repaired structures may change from ductile to brittle. Improvement of lateral capacity of masonry walls to resist in-plane moment in the longitudinal direction due to earthquakes was conducted by many researchers. Masonry panels reinforced with externally bonded CFRP laminates and sheets subjected to in-plane shear load were investigated [4]. Panels with two configurations of the reinforcement were subjected to monotonic and cyclic loading. The undesirable systems of discrete wall piers created in structures with large openings were particularly weak in resisting seismic loads. Using hold-down vertical forces have gain excellent strength, stiffness, and ductility. However, the undesirable compressive mode of failure of wall piers could be occurred. A displacement-based design procedure could be used to design the energy dissipation devices required for wall piers stability [5]. They developed a simple mechanics model for the nonlinear load-deformation relationship of the stabilized piers which was accurate enough for design purposes. The vulnerability and the overall seismic behavior of masonry building were investigated [6]. A methodology for seismic design and evaluation of the response of the masonry structures were developed. Four- story masonry residential buildings instead of multi-story reinforced concrete, $\mathrm{RC}$, were proposed [7]. They verified that it is possible to construct a four-story residential building with masonry bearing walls instead of RC beam and column skeleton system without changing its architectural characteristics. The use of Ferro-cement as strengthening components for the repair and strengthening of RC beams was reviewed and investigated [8]. In general, the damaged concrete was removed and replaced with ferrocement, with or without any changes in overall dimensions of the beam. The beams were tested under static or cyclic loading conditions [9]. The strengthened beams were reported to exhibit improved cracking resistance, flexural stiffness and the ultimate loads compared to the original beams. Other technical methods used for repair of RC structures are epoxy injection and cement grouting techniques. These techniques are widely used to treat cracking problems in concrete. The procedure used was well established in the literature [10-12]. Efficiency of repair works was evaluated by testing the repaired structures under seismic loads. Crack repair methods may have a positive effect, but may change the pattern of collapse of structure which requires to be considered when assessing these methods. Crack repair methods may also contribute to improve the obtained structure integrity with multiple advantages [13].

Barrages are considered one of the most important water structures in Egypt. They control water levels in the River Nile and its branches and canals. It is very important to keep them working in good condition to assure good water management and distribution process. Most of these barrages have been built many years ago using masonry bricks without steel reinforcement and they are still in service till now. The construction cost of $\mathrm{RC}$ barrages is much higher than masonry barrages. The main problem of the masonry structures is their low resistance to lateral load especially in the out of plane direction which causes over stress in the barrage piers during earthquakes. The effect of using reinforcement and pre-stressing techniques for strengthening masonry piers to increase the seismic load capacity of barrage piers in the out of plane direction was investigated [14].

Journal of Engineering Sciences, Assiut University, Faculty of Engineering, Vol. 41, No. 4, July, 2013,E-mail address: jes@aun.edu.eg 
Ahmed S. Hashad, Mohamed I. Abukhashaba, Seismic evalution of cracked masonary barrage piers repaired with different methods, pp. $1406-1420$

The current research presents a study on the effects of applying different repair techniques on the dynamic structural response of masonry barrage piers. These techniques have been selected for their potential to either increase the structural capacity of the repaired masonry cracked piers or to restore its original capacity.

\section{Experimental procedure}

In order to investigate the effect of various repair techniques on the seismic structural response of masonry piers, a total of four masonry piers having a dimension of $460 \mathrm{~mm}$ long, $220 \mathrm{~mm}$ wide and $1250 \mathrm{~mm}$, height were built on the shaking table using commercial traditional clay perforated bricks, that commonly produced in Egypt and used nowadays in most of masonry applications, to model the barrage piers, and tested. For piers constructing process, the bricks were arranged as shown in Fig. 1. Four steel bars of mild steel with $8 \mathrm{~mm}$ diameter fixed in staggered arrangement reinforcements were used for one of masonry piers, while two tie rods of high grade steel with $10 \mathrm{~mm}$ diameter were used for applying pre-stressing force of 1 ton for one other pier. All masonry piers were built on a foundation layer consists of plain concrete with $70 \mathrm{~mm}$ thickness. Fig. 2 shows the tested piers built on the shaking table. Table 1 illustrates the material properties.

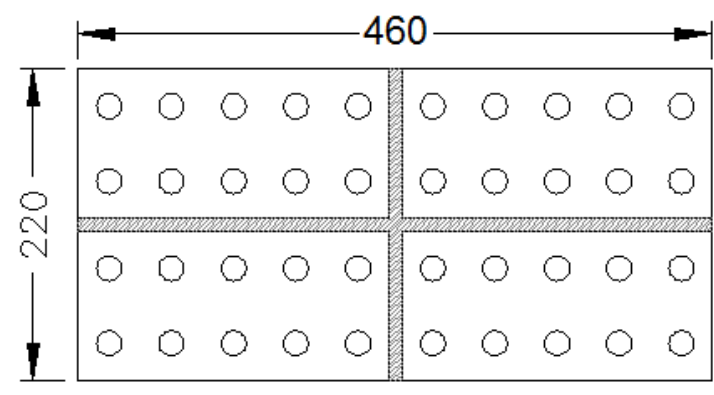

a) Course No. 1

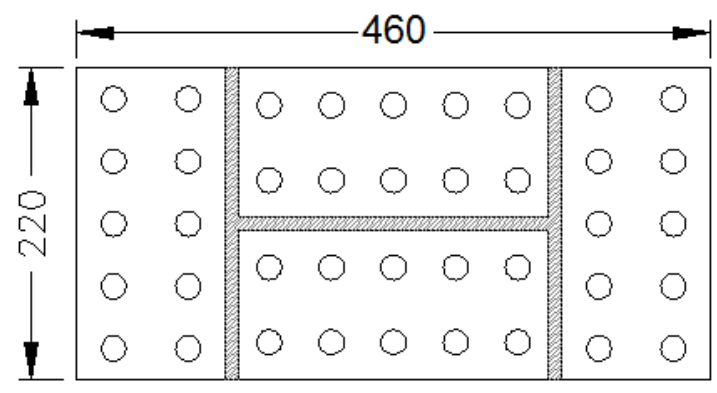

b) Course No. 2

All dimensions in $\mathrm{mm}$

Fig. 1. Brick arrangement used in piers construction

All piers were built using ordinary techniques for masonry buildings. The piers were built at the same time with the same brick and mortar type and with the same labors. For quality control purpose, five prisms were prepared based on Egyptian standard [15]. The prisms were built with the same mortar used for constructing the tested piers. They were tested in compression to estimate the average compressive strength of the tested piers. The compressive strength was found in the range of 3.2 to $3.8 \mathrm{~N} / \mathrm{mm}^{2}$ with the average of 3.5 $\mathrm{N} / \mathrm{mm}^{2}$ with acceptable degree of convergence among the tested prisms. This convergence proofs that all the tested piers have the same average strength. Fig. 3 shows some of the tested prism specimens after being failed under the compression test.

Journal of Engineering Sciences, Assiut University, Faculty of Engineering, Vol. 41, No. 4, July, 2013,E-mail address: jes@aun.edu.eg 
Ahmed S. Hashad, Mohamed I. Abukhashaba, Seismic evalution of cracked masonary barrage piers repaired with different methods, pp. $1406-1420$

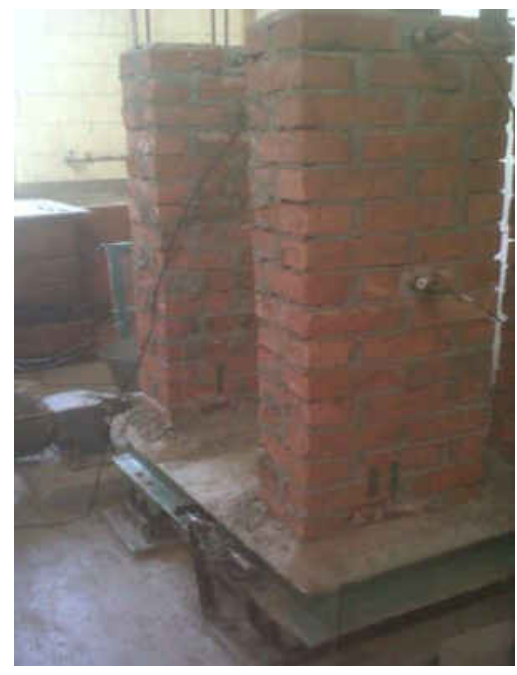

Fig. 2. Masonry piers built on shaking table.

\section{Table 1.}

The used material properties

\begin{tabular}{|c|c|c|c|}
\hline Property & Concrete & D8 & D10 \\
\hline $\begin{array}{c}\text { Density, } \\
\text { gm/cm }\end{array}$ & 1.6 & 7.8 & 7.8 \\
\hline $\begin{array}{c}\text { Tensile } \\
\text { modulus, GPa }\end{array}$ & 2 & 200 & 200 \\
\hline $\begin{array}{c}\text { Yield strength, } \\
\text { MPa }\end{array}$ & - & 320 & 400 \\
\hline $\begin{array}{c}\text { Tensile } \\
\text { strength, MPa }\end{array}$ & 2.3 & 410 & 580 \\
\hline Poisson's ratio & 0.2 & 0.3 & 0.3 \\
\hline
\end{tabular}

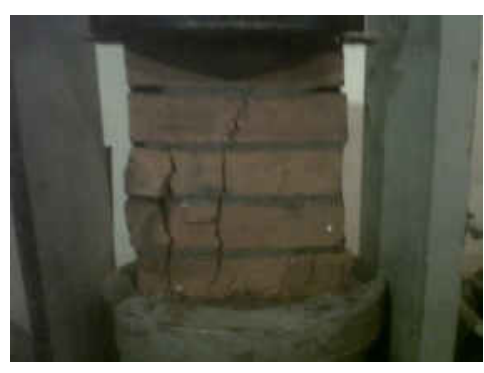

a) Sample No. 1

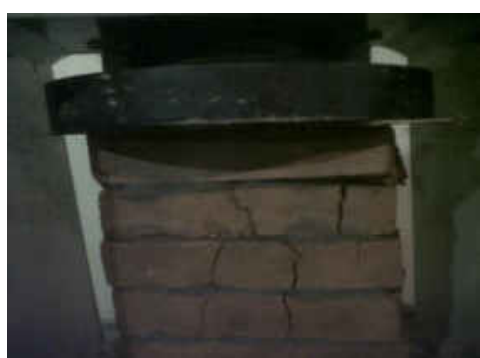

b) Sample No. 2

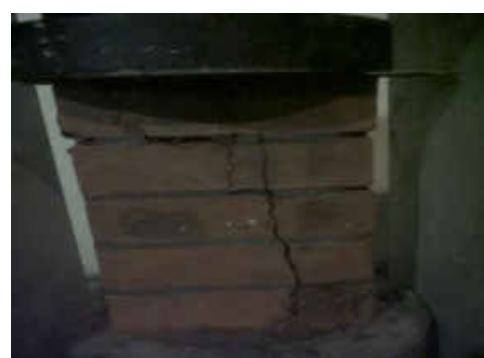

c) Sample No. 3

Fig. 3. Some tested prism samples under compression test.

Journal of Engineering Sciences, Assiut University, Faculty of Engineering, Vol. 41, No. 4, July, 2013,E-mail address: jes@aun.edu.eg 
Ahmed S. Hashad, Mohamed I. Abukhashaba, Seismic evalution of cracked masonary barrage piers repaired with different methods, pp. 1406 - 1420

\section{Damaged piers repair methodology}

One of the fourth piers called pier No. 1 represents the original sound uncracked case and left without strengthening to be a reference for the cracked-repaired cases. For the other three piers, an artificial crack was configured at the same level and almost covered the whole pier cross section. The three cracked piers were repaired by using three different crack repair techniques. One of the three cracked piers called pier No. 2 was repaired by pasted technique using epoxy while in the second pier named pier No. 3; the crack was stapled using reinforced steel bars. For the third pier which called pier No. 4, the crack was repaired by tied with anchored bolts. The configuration of stapled bars and tied anchors are shown in Fig. 4.

In practice the introduced repair methods can be applied for the actual piers and bearing walls. In case of stapled or tied technique, reinforced bars or anchors can be installed using accurately positioned drilled holes [16] and the proposed grouting is used to provide the bond between the masonry and reinforcement for stapled bars while in case of tied, the grout first generates concrete end block at certain level before applying the prestressing force then use grout to fill the hole. For pasted technique cracks will be injected with the selected epoxy resin as previously used for mortar grouting.

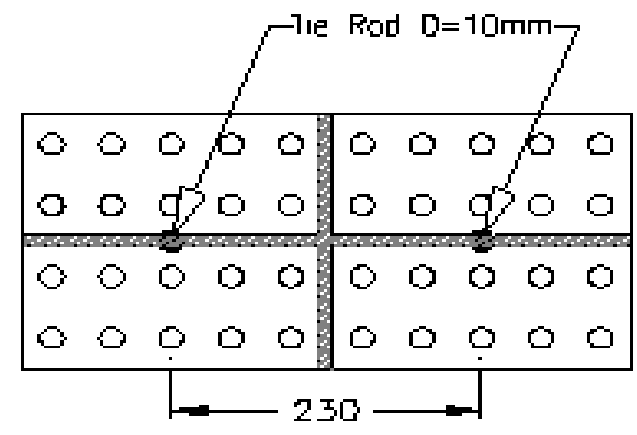

All dimensions are in $\mathrm{mm}$

a) Tie Rod Configuration

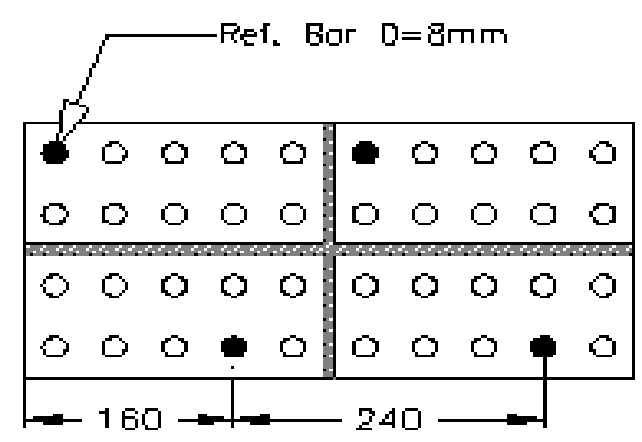

Fig. 4. Stapled bars and tied anchors configuration.

For the purpose of experiments simplicity, piers No. 3 and 4 were prepared during construction process. The third pier was stapled by using steel bars to simulate the reinforced masonry walls techniques. The steel bars used were four mild steel bars with $8 \mathrm{~mm}$ diameter fixed in a staggered arrangement. The steel bars were fixed inside the brick holes as demonstrated in Fig. 4 sketch. Then, these holes were filled with mortar. Figure (5-a) shows the steel bars inside the brick holes. The fourth pier was constructed as the first pier but was provided with two tie rods of high grade steel with $10 \mathrm{~mm}$ diameter to carry pre-stressing force $=1$ ton. The tie rods were put in a plastic pipe during the construction of the pier to apply the pre-stressing force after construction completion of the pier and gain its stress resistance. Figure (5-b) shows the tie rods inside plastic pipes. Figure (5-c) displays pier No. 2 in which the epoxy was used to paste the crack.

Journal of Engineering Sciences, Assiut University, Faculty of Engineering, Vol. 41, No. 4, July, 2013, E-mail address: jes@aun.edu.eg 
Ahmed S. Hashad, Mohamed I. Abukhashaba, Seismic evalution of cracked masonary barrage piers repaired with different methods, pp. $1406-1420$

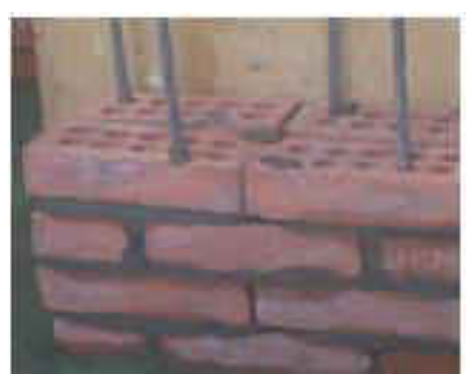

a) Stapled Pier

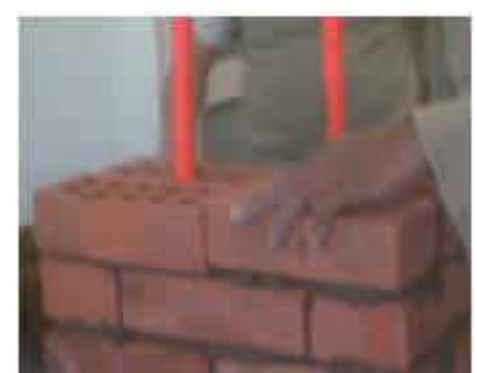

b) Tied Pier

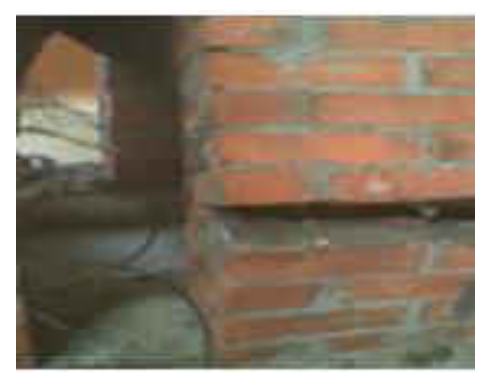

c) Pasted Pier

Fig. 5. Tested models during construction.

The crack level was determined from previous set of experiments carried out on piers similar to the original one [14]. The pier was subjected to base vibration load. The acceleration of the vibration load was continuously increased until failure occurs. The location of crack causing failure was then determined. Fig. 6 shows the location of crack causing pier failure. This location considered the most critical section and a similar crack was initiated in the other three piers using saw cut technique as shown in Fig. 7.

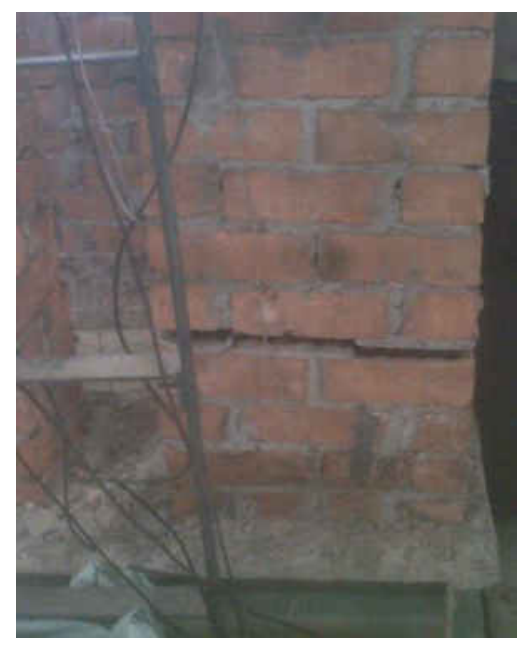

Fig. 6. Crack location determination test.

Journal of Engineering Sciences, Assiut University, Faculty of Engineering, Vol. 41, No. 4, July, 2013,E-mail address: jes@aun.edu.eg 


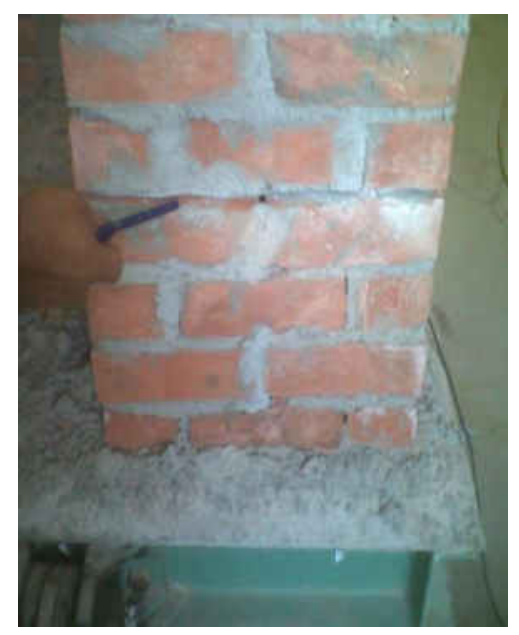

Fig. 7. Artificial crack formation.

\section{Test set-up}

The responses of the piers were measured using accelerometer sensors. Three accelerometers were used to measure each pier acceleration response. The accelerometers were fixed at the top of each pier where maximum response was expected. Figure 8 displays the instrumentation devices used in the tests and its location on tested piers. The accelerometer sensors send the measured signals to a conditioner unit which in turn sends the conditioned signal to a data acquisition card through connecting cables. The acquisition card passes the digital data to a laptop computer for the purpose of data storage and analysis. The logging software controls the measuring process and converts analog signals to digital ones. The data is filtered and analyzed using the signal processing techniques. These techniques were applied on the measured acceleration- time record. These techniques such as Cut-off frequency technique filter are used to remove noises to get acceptable signal-to-noise ratio. The type of the data acquisition cards is PCD-320A. The software produced by KYOWA is used to control and filter the measurements. The data analysis software used is Mescope. The time lengths of input harmonic excitations were $20 \mathrm{sec}$. while the sampling rate was $100 \mathrm{sample} / \mathrm{sec}$. A low pass filter with $40 \mathrm{hz}$ cut off frequency was applied to overcome signal noise problems.

\section{Load history (input motions)}

The acceleration responses during shaking the piers were measured. The piers were subjected to three input motions with three different frequencies and with $20.0 \mathrm{sec}$. time length before applying crack pattern and then repeated after applying crack pattern and repair techniques to compare directly the effect of repair technique on the pier dynamic behavior. The frequencies of

Journal of Engineering Sciences, Assiut University, Faculty of Engineering, Vol. 41, No. 4, July, 2013, E-mail address: jes@aun.edu.eg 


\section{3}

Ahmed S. Hashad, Mohamed I. Abukhashaba, Seismic evalution of cracked masonary barrage piers repaired with different methods, pp. $1406-1420$

the applied motions were $1.17,1.75$, and $2.10 \mathrm{hz}$ respectively. Figure 9 displays the different input motion. The piers were subjected to other set of input motions with higher frequencies till failure occurs. At input motion with frequency $2.55 \mathrm{hz}$ and peak acceleration $8.40 \mathrm{~m} / \mathrm{sec}^{2}$, the original pier was failed then after a few seconds the pasted pier was also failed. The last two piers still resist the base motion load till the tied pier slipped over the shaking table as a one unit. The slipping failure occurs at base motion load with frequency $3.57 \mathrm{hz}$ and peak acceleration 16.70 $\mathrm{m} / \mathrm{sec}^{2}$. The stapled pier could stand against base motion with frequency up to $4.28 \mathrm{hz}$ and peak acceleration $24.00 \mathrm{~m} / \mathrm{sec}^{2}$.

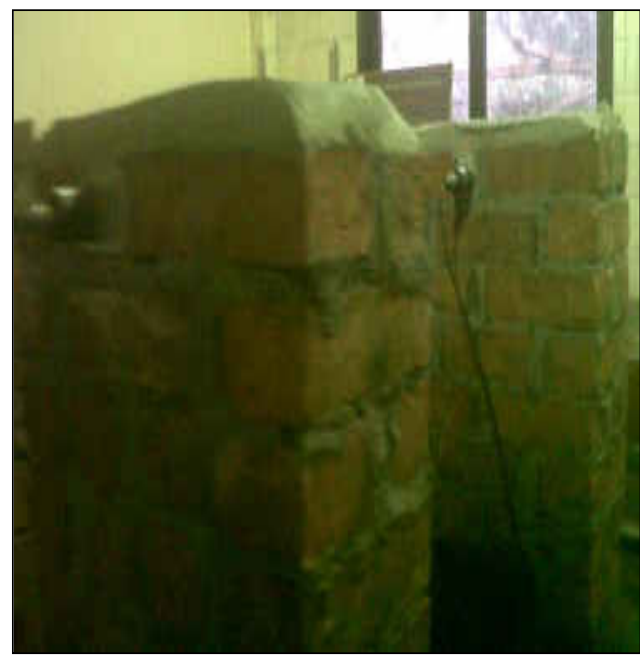

a) Pier photo

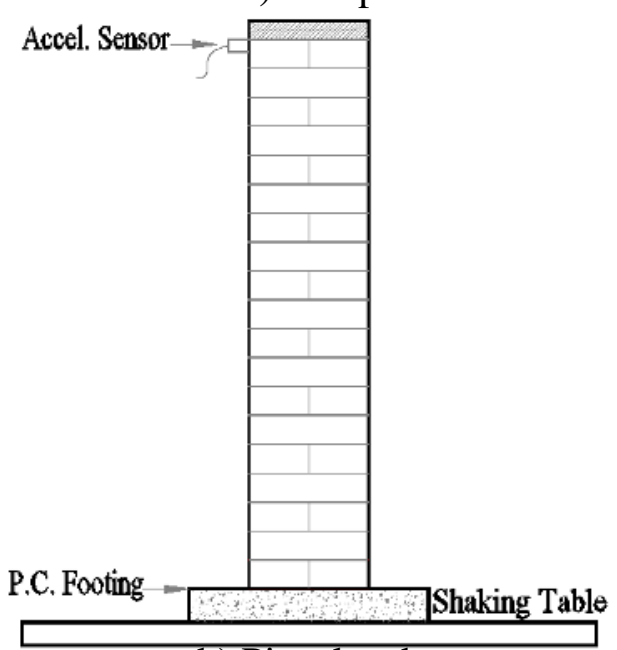

b) Pier sketch

Fig. 8. Some instrumentation mounting tested masonry piers.

Journal of Engineering Sciences, Assiut University, Faculty of Engineering, Vol. 41, No. 4, July, 2013,E-mail address: jes@aun.edu.eg 
Ahmed S. Hashad, Mohamed I. Abukhashaba, Seismic evalution of cracked masonary barrage piers repaired with different methods, pp. $1406-1420$
a) Input Motion with freq $=1.17 \mathrm{hz}$.
b) Input Motion with freq $=1.75 \mathrm{hz}$..
c) Input Motion with freq $=2.10 \mathrm{hz}$
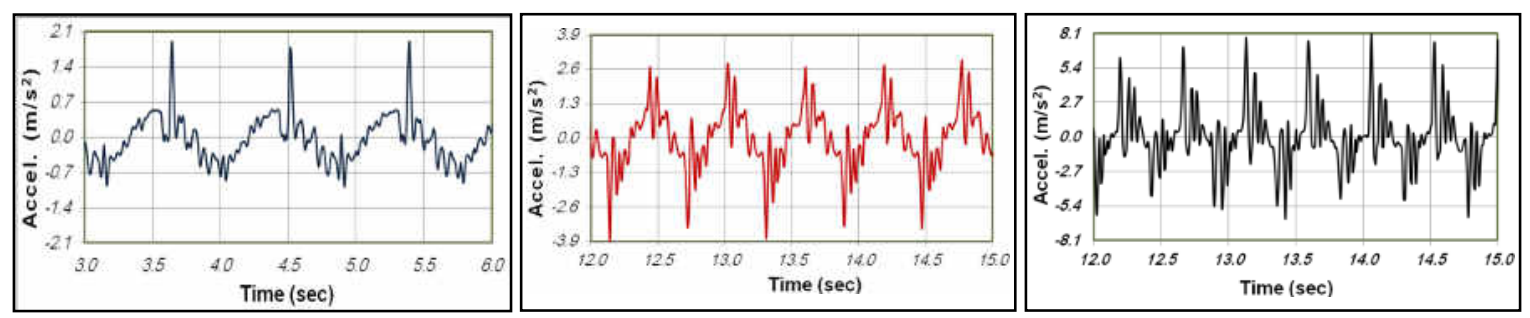

Fig. 9. Some input motions applied on the tested piers.

\section{Results and analysis}

For each repair technique a comparison between the acceleration response for the uncracked situation and the repaired crack one was done for the same repair technique. Figures (10-a), (10-b) and (10-c) display the pseudo acceleration responses for uncracked and the crack repaired situation for tied pier, pasted pier and stapled pier respectively. Results clarify that both pasted and tied techniques increased the rigidity for the pier while the rigidity for stapled pier was decreased. The results were matched with tests methodology, since the crack was induced firstly and then bonded with a strong material which is responsible for increasing the rigidity in the first case. Moreover, the crack was also induced in the tie-case and then applying the prestressing force, while in the staplecase the crack was induced in the whole section which was reinforced from the beginning and the crack was left as it was and the reinforcing bars were used to provide the staple effect which weakens the section.

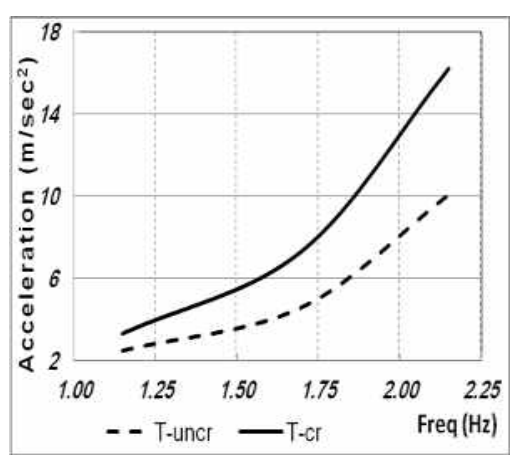

a) Tied Pier

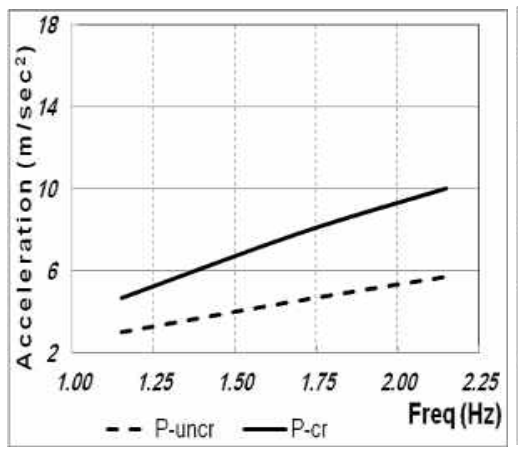

b) Pasted Pier

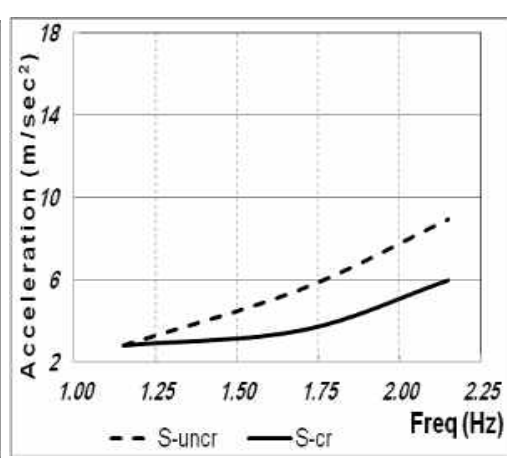

c) Stapled Pier

Fig. 10. Effect of crack on peak acceleration response for different repair technique.

The acceleration-time responses for the tested piers are displayed in Fig. 11. These responses are examined under the applied input motions with frequency $2.10 \mathrm{hz}$ and peak ground acceleration $6.94 \mathrm{~m} / \mathrm{sec}^{2}$.

Journal of Engineering Sciences, Assiut University, Faculty of Engineering, Vol. 41, No. 4, July, 2013,E-mail address: jes@aun.edu.eg 
Ahmed S. Hashad, Mohamed I. Abukhashaba, Seismic evalution of cracked masonary barrage piers repaired with different methods, pp. 1406 - 1420

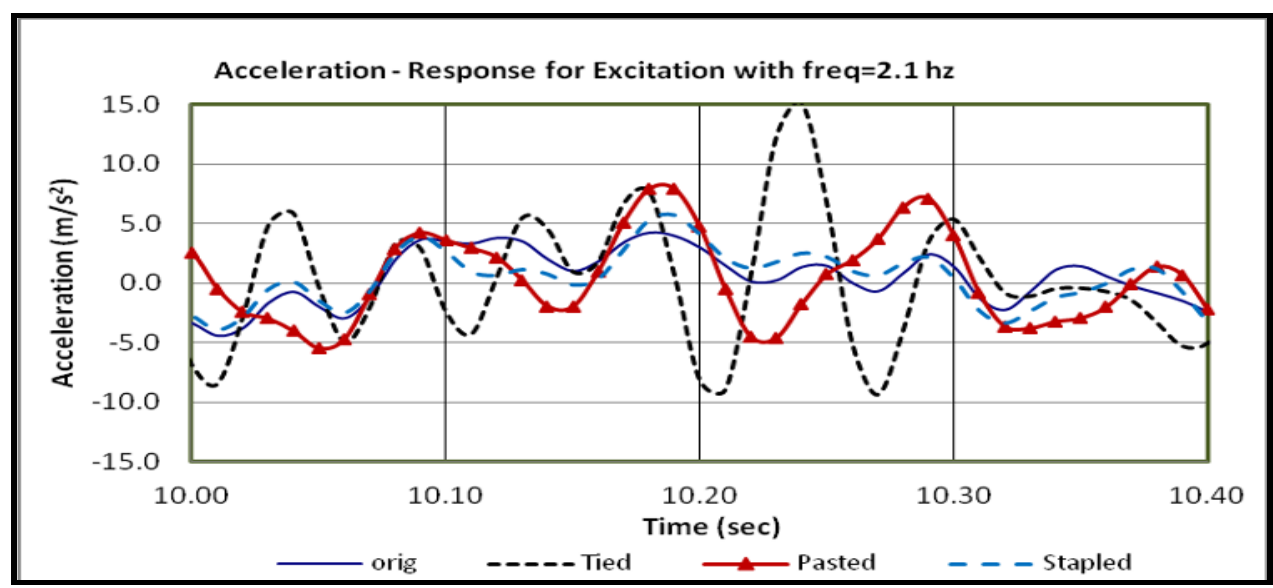

Fig. 11. Acceleration responses time wave form for the tested piers.

The results of the tests showed that the acceleration response of the stapled pier is the most similar to the original pier. Pasted pier has a degree of convergence with the original pier while the acceleration response of tied pier has different trend than other piers.

This behavior can be clarified by plotting the peak acceleration response against the input motion frequency. Figure 12 displays the relation between the pack acceleration response and input motion frequency for the four piers. For input motion frequency lower than $2.50 \mathrm{hz}$, a considerable convergence between original pier and stapled pier can be recognized. The pasted pier has a similar dynamic behavior pattern as the original pier with almost constant shift in its acceleration response. The tied pier showed a different dynamic behavior than other repair techniques.

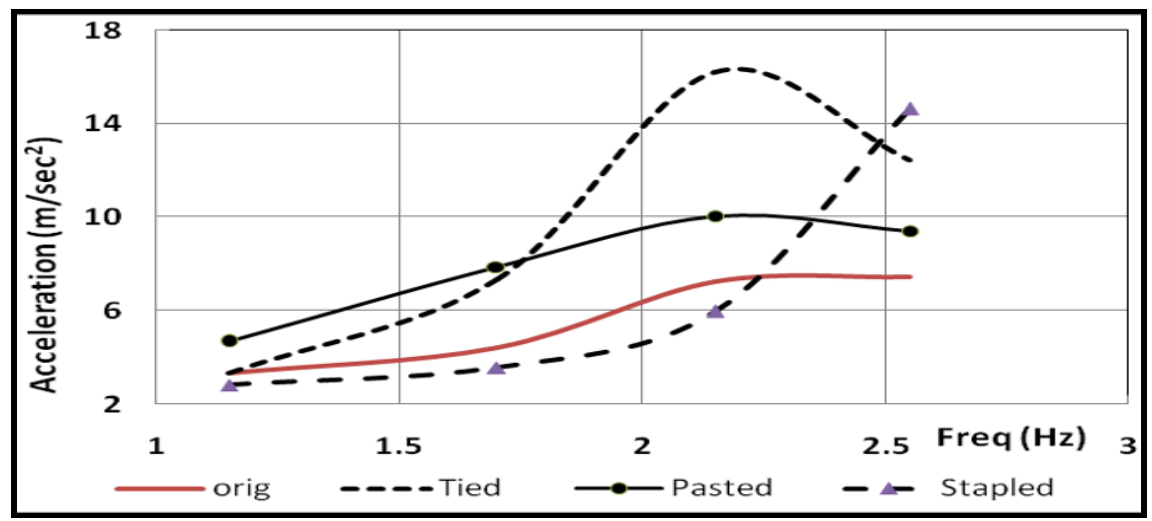

Fig. 12. Peak acceleration responses for the tested piers.

Generally, test results showed that all the repaired piers were able to stand against lateral loads with efficiency more than the uncracked pier. Although, the pasted technique

Journal of Engineering Sciences, Assiut University, Faculty of Engineering, Vol. 41, No. 4, July, 2013,E-mail address: jes@aun.edu.eg 
Ahmed S. Hashad, Mohamed I. Abukhashaba, Seismic evalution of cracked masonary barrage piers repaired with different methods, pp. 1406 - 1420

enhance the pier seismic resistance but its effect was limited comparing to tied and stapled techniques. Tied technique upgrades the pier seismic resistance, however, some cautions must be considered when using this technique to overcome the base shear failure. Finally, stapled technique was the most efficient one and its seismic resistance almost comes from ductility and damping due to forming cracks. Even though, this solution may not be appropriate for water structures since allowing many cracks that increase the capability of the structure to absorb the side load energy but also it represents another type of failure for water structure which is not allowed. Moreover, the used stapled technique depends on distributing the stresses along a larger area of the structure and not only in the limited region above and down the crack which can contribute in increasing the repair cost.

\section{Failure modes of the tested repaired piers}

The failure pattern for original pier, pasted pier and tied pier are showed in Figures (13-a), (13-b) and (13-c) respectively. The stapled pier was the last failed one. The pier failed also due to slipping failure but there are several cracks were formed on different location before slipping failure occurs. The formed cracks almost converted the pier into segments blocks connected by stapled bars. Figure 14 displays the formed cracks.

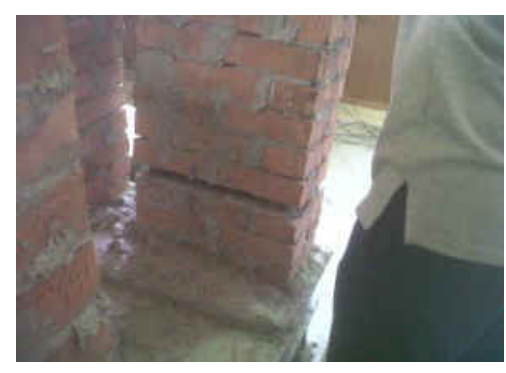

a) Original Pier

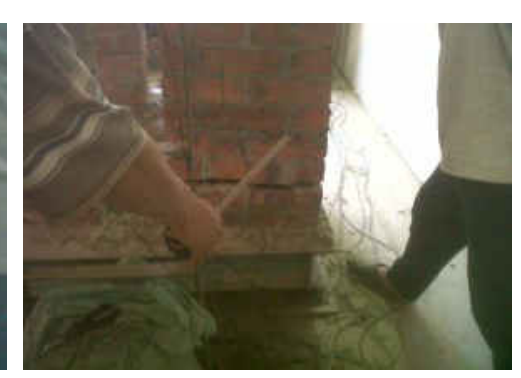

b) Pasted Pier

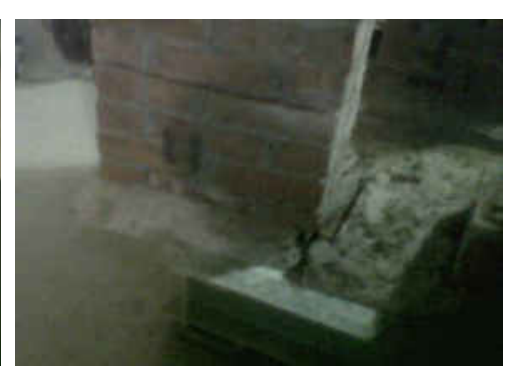

c) Tied Pier

Fig. 13. Failure pattern for repaired piers.

Since the purpose of tied and stapled repair technique was not only to retrieve the repaired pier crack to its original condition but also to increase its seismic resistance. Therefore, a comparison between the dynamic behavior of the tied pier and stapled pier were carried out to evaluate the most effective technique.

The peak acceleration response under the effect ground motions with different frequencies was investigated. The applied ground motions varied from slight motions till motion causing pier failure. Figure 15 shows the relation between the peak acceleration response and the frequency of input motion applied on tied and stapled pier. It could be noticed from the plots that the stapled pier could stand against wider range of ground acceleration frequencies without failure than the tied technique. Also the dynamic behavior of the stapled technique showed lower acceleration responses than tied technique for most of the input ground motion.

Journal of Engineering Sciences, Assiut University, Faculty of Engineering, Vol. 41, No. 4, July, 2013,E-mail address: jes@aun.edu.eg 
Ahmed S. Hashad, Mohamed I. Abukhashaba, Seismic evalution of cracked masonary barrage piers repaired with different methods, pp. $1406-1420$
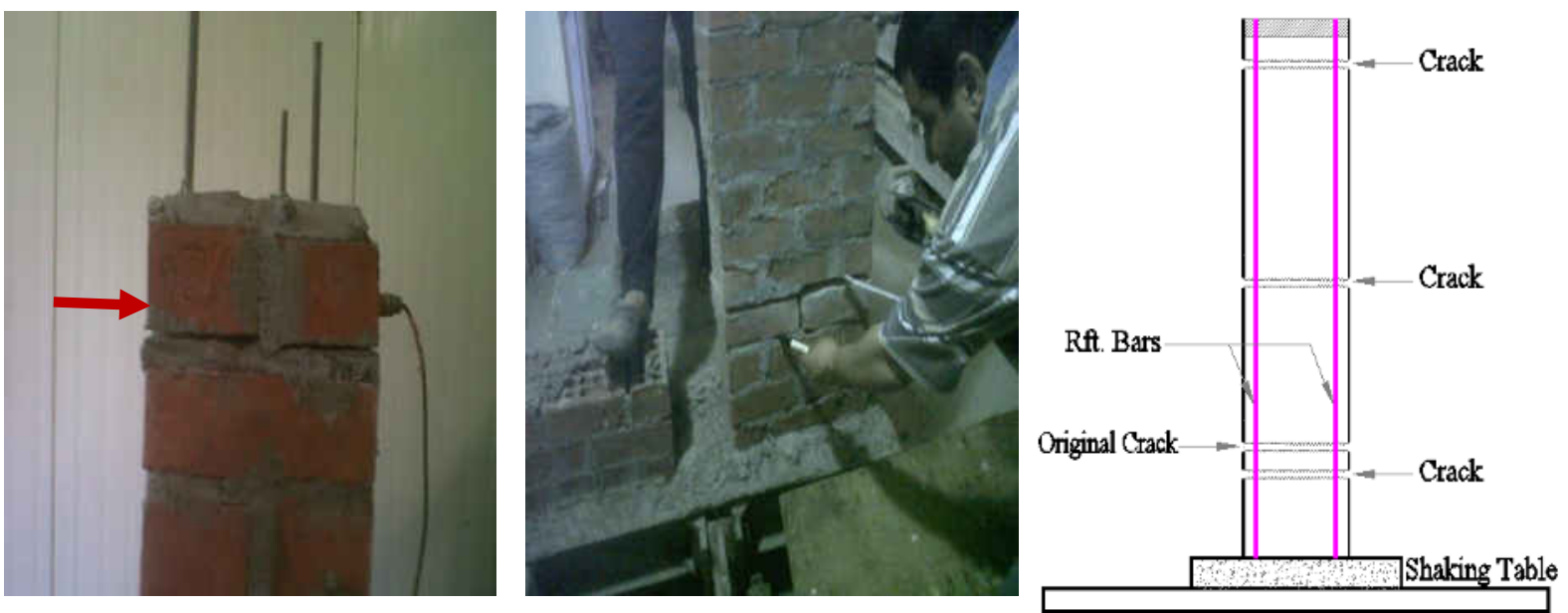

Fig. 14. Failure pattern for stapled piers.

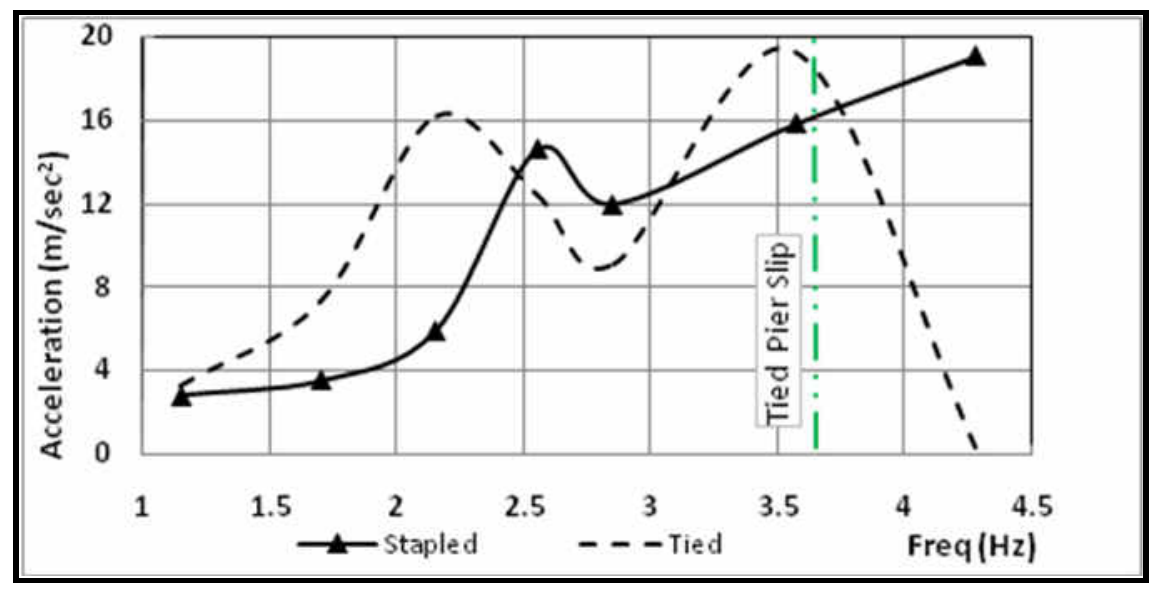

Fig. 15. Relation between peak acceleration response and frequency of input motion for tied and stapled pier.

The crack surface for all the piers were inspected to know the type of stresses causing failure. Fig. 16 shows the typical crack surfaces for failed piers. From the inspection processes, the major reasons of failure was due to debonding (bond failure) between mortar and bricks at the crack surface passing between the mortar layer and the bricks without causing any damages for either mortar or bricks. The mortar layer was almost

Journal of Engineering Sciences, Assiut University, Faculty of Engineering, Vol. 41, No. 4, July, 2013,E-mail address: jes@aun.edu.eg 
Ahmed S. Hashad, Mohamed I. Abukhashaba, Seismic evalution of cracked masonary barrage piers repaired with different methods, pp. $1406-1420$

pulled out with keeping its shape that was previously formed after hardening during pier construction.
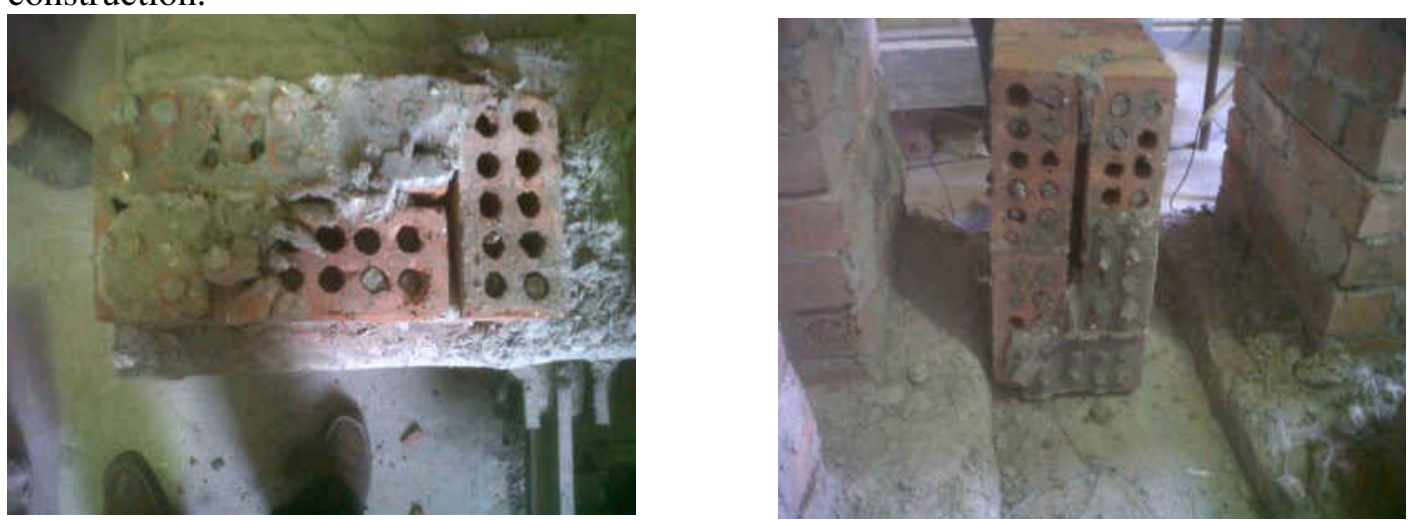

Fig. 16. Typical crack surfaces for failed piers.

\section{Conclusions}

The results of the current study lead to the following conclusions:

1. All the repaired piers were able to stand against lateral loads with efficiency more than the uncracked pier. The appropriate repairing technique should be selected according the situation in the nature.

2. The pasted technique could also enhance the pier seismic resistance. However, its effect was limited comparing to both tied and stapled techniques.

3. The use of pre-stressed and reinforced masonry could prevent the brittle failure occurred in the ordinary masonry piers.

4. The reinforced masonry had damping effect higher than that of pre-stressed masonry. Therefore, it can be used in new structures.

5. The pre-stressed technique can be used in the strengthening of existing structures because of the difficulty of making many holes in existing pier in the case of using reinforced masonry technique. However, some cautions should be considered when using this technique to overcome the base shear failure.

6. Stapled technique was the most efficient one and its seismic resistance almost comes from ductility and damping due to forming many cracks. However, this solution may not be appropriate for water structures since allowing many cracks that increase the capability of the structure that represents another type of failure for water structure which is not allowed.

7. In practice the investigated repair methods can be applied in the nature. In case of stapled/tied technique, reinforced bars or anchors are installed using accurately positioned drilled holes and grouting is used to provide the bond between the masonry and reinforcements while applying the grout firstly to provide end block at the required level before applying the prestressing force then use grout to fill in the hole.

Journal of Engineering Sciences, Assiut University, Faculty of Engineering, Vol. 41, No. 4, July, 2013, E-mail address: jes@aun.edu.eg 
Ahmed S. Hashad, Mohamed I. Abukhashaba, Seismic evalution of cracked masonary barrage piers repaired with different methods, pp. $1406-1420$

For pasted technique cracks will be repaired by injecting the epoxy mortar till closing the occurred cracks.

\section{References}

[1] Waleed, A., Thanoon, Jaafar, M.S., Razali, M., Kadar, A., and Noorzaei, J., "Repair and Structural Performance of Initially Cracked Reinforced Concrete Slabs", Construction and Building Materials 19, pp. 595-603, 2005.

[2] Clarke, J.K., and Waldron, P., "The Reinforcement of Concrete Structures with Advanced Composites", Structural Eng., 74(17/3), 1996.

[3] Arduni M., Tommaso, A.D., and Nanni, A., "Brittle Failure in FRP Plate and Sheet Bonded Beams", ACI Structural J., 94:363-70, 1997.

[4] Hernan, S., Gonzalo, D., and Alejandro G.,"Experimental Investigation of Masonry Panels Externally Strengthened with CFRP laminates and Fabric Subjected to In-plane Shear Load", 13-th World Conference on Earthquake Engineering, Paper No. 1627, Canada, 2004.

[5] Durgesh, C., and Subhash, C., "Seismic Strengthening of Rocking-Critical Masonry Piers", Journal of Structural Eng., Vol. 133, No. 10, ASCE, pp. 1445-1452, 2007.

[6] Fotis, P., and, Costas, A., "Aseismic Design and Reinforcement Recommendations of a Masonry Structure Using Fragility Curves", Master Thesis, School of Civil Engineering, National Technical University, Athens, 2011.

[7] Asli, A., "A Comparative Study on Earthquake Resistance of Reinforced Concrete and Masonry Residential Buildings in Small-Scale Cities of Turkey", Ph.D. Thesis, The Graduate School of Natural and Applied Science, Middle East Technical University, Turkey, 2008.

[8] Romualdi J.P., Lim C.T.E., and Ong, K.C.G., "Strengthening of RC Beams with Ferrocement laminates", Cement Concrete Composite, 20:53-65, 1998.

[9] Paramasivam, P., "Laminated Ferrocement for Better Repair", Concrete Int., Design Construction, 9:34-8, 1987.

[10] Emmons, P.H., "Concrete Repair and Maintenance", R.S. Means INC, 1994.

[11] Allen, R.T.L., Edwards, S.C., "The repair of Concrete Structures", Blackie, 1987.

[12] Raina, V.K., "Concrete Bridge Practice-Construction, Maintenance and Rehabilitation", 2nd ed., New Delhi, Tata McGraw Hill, 1993.

[13] Robet, G., Ahmed, A., and, Lawrie, R., "Masonry Structures Behavior and Design", the Masonry Society, Boulder Colorado, USA, 1999.

[14] El-Hakem, Y., and Hashad, A., "Assessment of Using Reinforced and Pre-Stressed Masonry to Upgrade Lateral Load Capacity of Barrage Pier", 9th Int. Conference on Civil and Architectural Engineering, The Military Technical College, Egypt, 2012.

[15] National Research Center for Housing and Buildings, "Egyptian Code for Design and Construction of Building Works", Cairo, 2005.

[16] Brookes C.L., and Mullett P.J., "Service Load Testing, Numerical Simulation and Strengthening of Masonry Arch Bridges” Arch Bridges, ARCH’04, Barcelona, 2004.

Journal of Engineering Sciences, Assiut University, Faculty of Engineering, Vol. 41, No. 4, July, 2013, E-mail address: jes@aun.edu.eg 
Ahmed S. Hashad, Mohamed I. Abukhashaba, Seismic evalution of cracked masonary barrage piers repaired with different methods, pp. 1406 - 1420

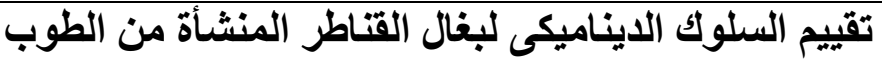 بعد إصلاح الشروخ الحادثة بها بأساليب إصلاح الصنام مختلفة}

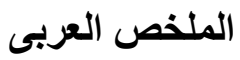

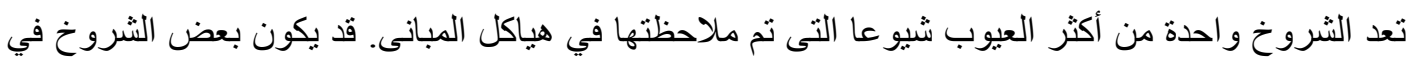

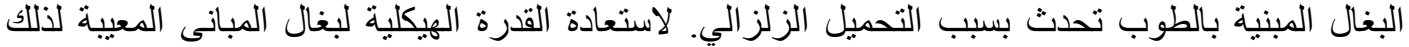

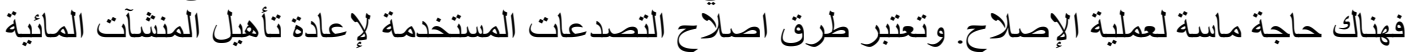

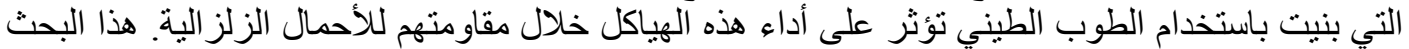

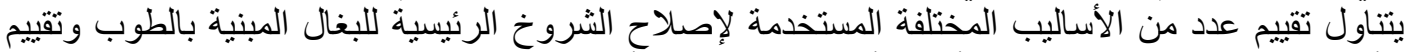

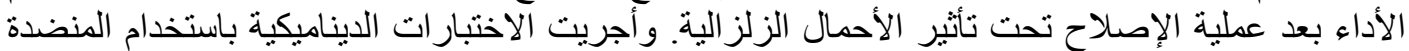

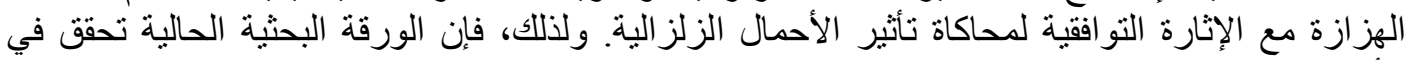

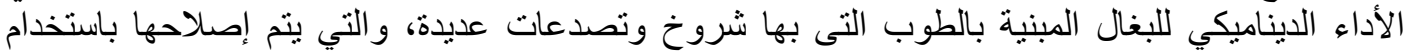

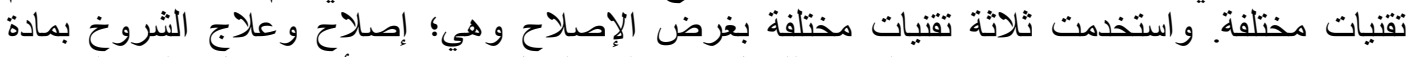

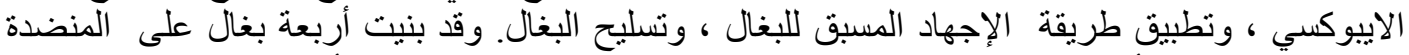

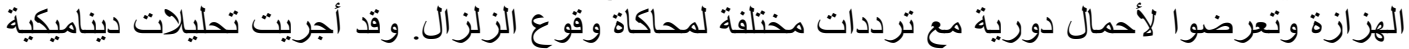

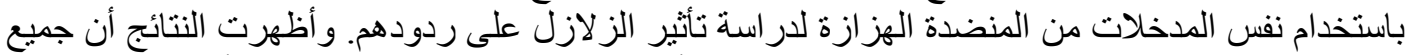

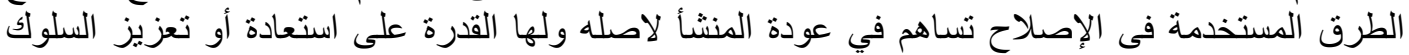

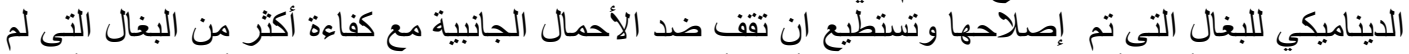

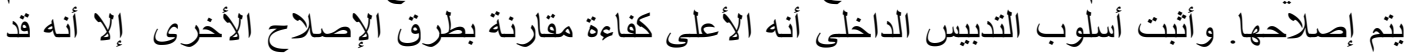

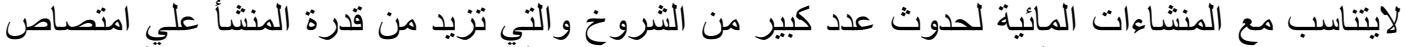

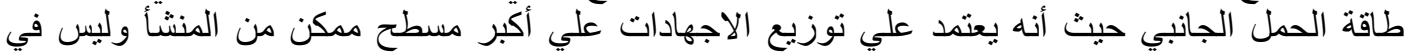

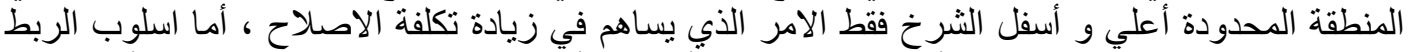

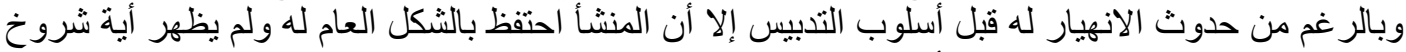

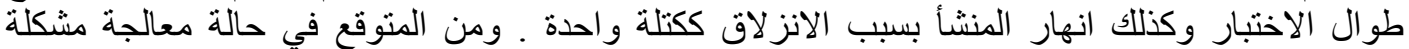

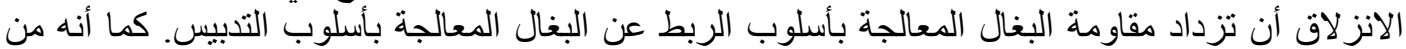

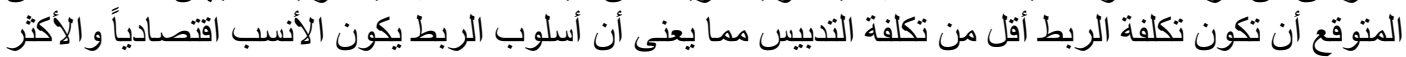

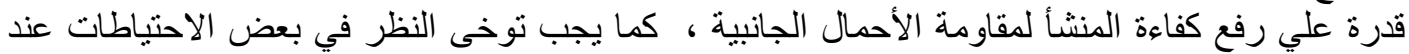

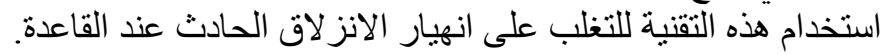

Journal of Engineering Sciences, Assiut University, Faculty of Engineering, Vol. 41, No. 4, July, 2013,E-mail address: jes@aun.edu.eg 